\title{
Karyotype of Latibulus argiolus (Rossi, 1790) (Hymenoptera: Ichneumonidae)
}

\section{Кариотип Latibulus argiolus (Rossi, 1790) (Hymenoptera: Ichneumonidae)}

\section{V.E. Gokhman ${ }^{1}$, A.Yu. Kosyakova ${ }^{2}$, L.Yu. Rusina ${ }^{3}$

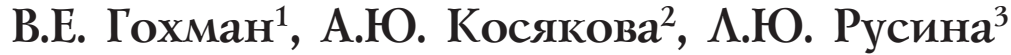

\footnotetext{
${ }^{1}$ Botanical Garden, Moscow State University, Moscow 119234, Russia. E-mail: vegokhman@hotmail.com

${ }^{2}$ Meshchera National Park, Gus-Khrustalny 601501, Russia. E-mail: ainsel@list.ru

${ }^{3}$ Moscow Zoo, Bolshaya Gruzinskaya Str. 1, Moscow 123242, Russia. E-mail: lirusina@yandex.ru

${ }^{1}$ Ботанический сад Московского государственного университета, Москва 119234, Россия.

2 Национальный парк «Мещера», Гусь-Хрустальный 601501, Россия.

${ }^{3}$ Московский зоопарк, Большая Грузинская ул., 1, Москва 123242, Россия.
}

KEY WORDS. Latibulus argiolus, Ichneumonidae, karyotype, chromosomes.

КЛЮЧЕВЫЕ СЛОВА. Latibulus argiolus, Ichneumonidae, кариотип, хромосомы.

ABSTRACT. Karyotype of Latibulus argiolus (Rossi, 1790) (Ichneumonidae), a widespread parasitoid of the wasp genus Polistes Latreille, 1802 (Vespidae), was studied for the first time using chromosome morphometrics. In this species, $n=9$ and $2 n=18$ were found. No karyotypic difference between the examined populations of $L$. argiolus from different host species and geographical regions was detected.

РЕЗЮМЕ. С использованием морфометрии хромосом впервые изучен кариотип Latibulus argiolus (Rossi, 1790) (Ichneumonidae), широко распространённого паразитоида ос рода Polistes Latreille, 1802 (Vespidae). Обнаружено $n=9$ и $2 n=18$. Кариотипические различия между исследованными популяциями $L$. argiolus, связанными с разными видами хозяев и географическими регионами, не обнаружены.

\section{Introduction}

Parasitoid Hymenoptera are one of the most speciose, taxonomically complicated and economically important insect groups, with their estimated number of species in the world fauna far exceeding one million [Quicke, 1997; Bebber et al., 2014; Forbes et al., 2018]. Among parasitic wasps, Ichneumonidae represent the most diverse family that harbors more than 24 thousand described species [Huber, 2017]. The subfamily Cryptinae is the largest group of the Ichneumonidae which includes about 400 genera and 4500 described species [Quicke, 2015]. However, chromosomes of only nine cryptine ichneumonids are examined up to now, as opposed to more than 150 karyotypically studied members of the family that belong to other subfamilies of the Ichneumonidae [Gokhman, 2009]. We have studied for the first time chromosome sets of two populations of Latibulus argiolus (Rossi, 1790), a well-known parasitoid of the wasp genus Polistes Latreille, 1802 (Vespidae) [Makino, 1983; Rusina, 2013]. The results of this study are given below.

\section{Material and methods}

Nests of Polistes nimpha (Christ, 1791) and P. gallicus (Linnaeus, 1761) used in the present study were respectively collected by A.Y. Kosyakova and A.I. Rusin on Pinus sylvestris Linnaeus (Snokhino, Klepikovsky District, Ryazan Province, Russia: $55^{\circ} 08^{\prime} \mathrm{N}$; 403' E) and Grindelia squarrosa (Pursh) (outskirts of Kherson, Kherson Province, Ukraine: $46^{\circ} 40^{\prime} \mathrm{N}$; $32^{\circ} 37^{\prime} \mathrm{E}$ ) in August and September 2019. Cocoons containing last-instar larvae of the overwintering second generation of $L$. argiolus were extracted from the nests, kept at 5 to $7^{\circ} \mathrm{C}$ for a few weeks, and then kept at room temperature either for obtaining prepupae for the karyotypic analysis or for rearing adult individuals. Reared specimens of $L$. argiolus were identified by the first author using the key provided by $\mathrm{Oh}$ et al. [2012].

Chromosome preparations were made from cerebral ganglia and developing testes of five parasitoid prepupae and early pupae using a modified version of the technique described by Imai et al. [1988]. Wasps were dissected in $0.5 \%$ hypotonic sodium citrate solution containing $0.005 \%$ colchicine, and the tissues were incubated in fresh solution for 30 minutes at room temperature. The material was transferred to a pre-cleaned microscope slide using a Pasteur pipette and gently flushed

How to cite this article: Gokhman V.E., Kosyakova A.Yu, Rusina L.Yu. 2020. Karyotype of Latibulus argiolus (Rossi, 1790) (Hymenoptera: Ichneumonidae) // Russian Entomol. J. Vol.29. No.4. P.421-422. doi: 10.15298/ rusentj.29.4.09 
with Fixative I (glacial acetic acid: absolute ethanol: distilled water $3: 3: 4)$. Tissues were disrupted in an additional drop of Fixative I using dissecting needles. Another drop of Fixative II (glacial acetic acid: absolute ethanol $1: 1)$ was then applied to the center of the area and blotted off the edges of the slide. The slide was air dried at room temperature. Preparations were stained with freshly prepared 3\% Giemsa solution in $0.05 \mathrm{M}$ Sorensen's phosphate buffer $\left(\mathrm{Na}_{2} \mathrm{HPO}_{4}+\mathrm{KH}_{2} \mathrm{PO}_{4}, \mathrm{pH}\right.$ 6.8).

Twenty-eight mitotic divisions were studied and photographed using an optic microscope Zeiss Axioskop 40 FL fitted with a digital camera Axiocam 208 color (Carl Zeiss, Germany). To obtain karyograms, the resulting images were handled with image processing programs ZEN version 3.0 (blue edition) and GIMP version 2.10. Chromosomes from the best four haploid metaphase plates were measured using KaryoType software version 2.0 to identify relative lengths (RLs) and centromeric indices (CIs) of chromosomes (Table 1) which were then classified using criteria provided by Levan et al. [1964].

\section{Results and discussion}

The haploid karyotype of $L$. argiolus contains nine chromosomes $(n=9)$ (Fig. 1). Among them, there are three long bi-armed chromosomes, i.e. two metacentrics and a submetacentric, three substantially shorter chromosomes (two acrocentrics and a metacentric/submetacentric), and another three apparently metacentric or submetacentric chromosomes (Table 1). Analogously, the diploid karyotype of this species harbors nine chromosome pairs $(2 \mathrm{n}=18$; image not shown).

L. argiolus became the second karyotypically studied member of the tribe Cryptini (= Mesostenini) [Gokhman, 2009]. However, the chromosome set of another species that belongs to this group, Mesostenus gracilis Cresson, 1864 with $\mathrm{n}=10$, strongly differs from that of L. argiolus by having all chromosomes of similar size as well as by the predominance of subtelocentrics and acrocentrics [Gokhman, 2009].

We failed to detect significant morphological or karyotypic difference between the two populations of $L$. argiolus from different host species and geographical

Table 1. Relative lengths and centromeric indices of chromosomes of $L$. argiolus (mean $\pm \mathrm{SD}$ ).

Таблица 1. Относительная длина и центромерный индекс хромосом $L$. argiolus (среднее \pm стандартное отклонение).

\begin{tabular}{c|r|r}
\hline $\begin{array}{c}\text { Chromosome } \\
\text { no. }\end{array}$ & RL & CI \\
\hline 1 & $19.75 \pm 0.89$ & $46.31 \pm 2.03$ \\
\hline 2 & $15.51 \pm 1.10$ & $45.48 \pm 4.22$ \\
\hline 3 & $13.78 \pm 0.68$ & $31.42 \pm 3.78$ \\
\hline 4 & $10.49 \pm 0.47$ & 0 \\
\hline 5 & $9.57 \pm 0.63$ & 0 \\
\hline 6 & $9.12 \pm 0.34$ & $38.47 \pm 5.34$ \\
\hline 7 & $7.97 \pm 0.30$ & $30.24 \pm 6.76$ \\
\hline 8 & $7.39 \pm 0.35$ & $36.00 \pm 6.20$ \\
\hline 9 & $6.42 \pm 1.03$ & $32.18 \pm 3.54$ \\
\hline
\end{tabular}

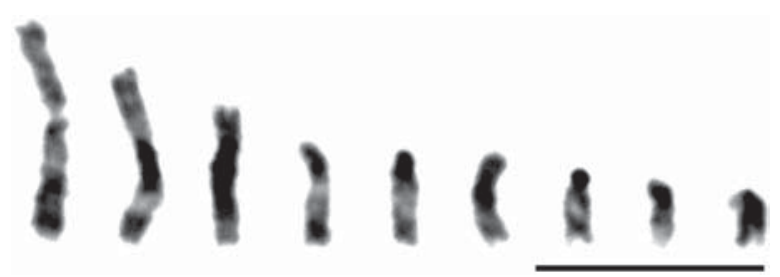

Fig. 1. Karyogram of haploid chromosome set of L. argiolus. Scale bar: $5 \mu \mathrm{m}$.

Рис. 1. Кариограмма гаплоидного хромосомного набора $L$. argiolus. Масштаб: 5 мкм.

regions. Although it seems possible that the chromosome study alone is unable to reveal putative cryptic species within L. argiolus, we also have a general belief that subdivision of a given parasitoid species into separate taxonomic entities is likely to be adaptive only if it attacks hosts with substantially different life-history strategies [Gokhman, 2018], and this is apparently not true in the case of L. argiolus.

Acknowledgements. The authors are grateful to A.I. Rusin (Gymnasium no. 20, Kherson, Ukraine) for collecting cocoons of $L$. argiolus from the nests of $P$. gallicus. The present work is partly supported by a research grant from the Russian Foundation for Basic Research no. 18-04-00611 to VEG.

\section{References}

Bebber D.P., Polaszek A., Wood J.R.I., Barker C., Scotland R.W. 2014. Taxonomic capacity and author inflation // New Phytologist. Vol.202. P.741-742. doi: 10.1111/nph.12745.

Forbes A.A., Bagley R.K., Beer M.A., Hippee A.C., Widmayer H.A. 2018. Quantifying the unquantifiable: Why Hymenoptera, not Coleoptera, is the most speciose animal order // BMC Ecology. Vol.18. Paper 21. doi: 10.1186/s12898-018-0176-x.

Gokhman V.E. 2009. Karyotypes of parasitic Hymenoptera. Dordrecht: Springer. XIII + 183 pp. doi: 10.1007/978-1-4020-9807-9.

Gokhman V.E. 2018. Integrative taxonomy and its implications for specieslevel systematics of parasitoid Hymenoptera // Entomological Review. Vol.98. No.7. P.834-864. doi: 10.1134/s0013873818070059.

Huber J.T. 2017. Biodiversity of Hymenoptera // Foottit R.G., Adler P.H. (eds). Insect biodiversity: science and society. 2nd edition. Oxford: Wiley Blackwell. P.419-461. doi: 10.1002/9781118945568.ch12

Imai H.T., Taylor R.W., Crosland M.W.J., Crozier R.H. 1988. Modes of spontaneous chromosomal mutation and karyotype evolution in ants with reference to the minimum interaction hypothesis // Japanese Journal of Genetics. Vol.63. P.159-185. doi: $10.1266 /$ jjg.63.159.

Levan A., Fredga K., Sandberg A.A. 1964. Nomenclature for centromeric position on chromosomes // Hereditas. Vol.52. P.201220. doi: 10.1111/j.1601-5223.1964.tb01953.x.

Makino S. 1983. Biology of Latibulus argiolus (Hymenoptera, Ichneumonidae), a parasitoid of the paper wasp Polistes biglumis (Hymenoptera, Vespidae) // Kontyû. Vol.51. No.3. P. 426-434.

Oh S.-H., An S.-L., Lee J.-W. 2012. Review of Korean Latibulus (Hymenoptera: Ichneumonidae: Cryptinae) and a key to the world species // Canadian Entomologist. Vol.144. P.509-525. doi: $10.4039 /$ tce.2012.54.

Quicke D.L.J. 1997. Parasitic wasps. London: Chapman \& Hall. XVII $+470 \mathrm{pp}$

Quicke D.L.J. 2015. The braconid and ichneumonid parasitoid wasps: biology, systematics, evolution and ecology. Oxford: Wiley Blackwell. XV + 681 pp

Rusina L.Y. 2013. The role of parasitoids in regulation of Polistes wasp population (Hymenoptera, Vespidae: Polistinae) // Entomological Review. Vol.93. No.3. P.271-280. doi: 10.1134/ s0013873813030019. 